\title{
The effect of wheat fibre on plasma lipids and faecal steroid excretion in man
}

\author{
BY R. M. KAY AND A. S. TRUSWELL \\ Department of Nutrition, Queen Elizabeth College, \\ Campden Hill, London $W 8{ }_{7} A H$
}

\begin{abstract}
I. The effect of isoenergetic substitution of bran and wholemeal bread for white flour and white bread was investigated in six healthy volunteers in a metabolic unit.

2. A 2 I $\mathrm{d}$ high-fibre experimental period was preceded and followed by a $14 \mathrm{~d}$ control period, so that each experiment lasted 7 weeks. Blood samples were taken on each of the last $3 \mathrm{~d}$ and faeces collected (using carmine markers) for the last $6 \mathrm{~d}$ of each diet period.

3. Plasma cholesterol, triglycerides and serum calcium concentrations were not altered by the addition of wheat fibre.

4. Wheat fibre caused a significant increase in faecal bulk and frequency. Faecal steroid excretion was the same in the last week of the first control and the high-fibre periods but increased in the subsequent control period.
\end{abstract}

There has been much recent interest in the hypothesis that dietary fibre may prevent coronary heart disease (CHD) (Trowell, I972 $a, b, 1975$; Trowell, Painter \& Burkitt, 1974). Consumption of wheat fibre is lower in Britain today than it used to be in the nineteenth century (Robertson, 1972) when CHD was uncommon, and we eat less cereal fibre than the populations of many developing countries which have low rates of $\mathrm{CHD}$ incidence. If large intakes of cereal fibre do indeed protect against CHD the most likely mechanism would be by reduction of plasma cholesterol concentration resulting from adsorption of bile salts or cholesterol to cereal fibre in the intestine with negative sterol balance. Eastwood \& Hamilton (r968) showed that lignin adsorbs bile acids in vitro. Wheat fibre consists of hemicellulose, cellulose and lignin in a ratio of 5:2: I by vol. (McConnell \& Eastwood, 1974). The reported effects of wheat fibre on plasma lipids both in man (Eastwood, 1969; Heaton \& Pomare, 1974) and animals (Kay \& Truswell, 1975) were conflicting and confusing when we started the present experiments. The practical question being tested was whether plasma cholesterol will fall when people eat brown bread instead of white or take extra bran, or both.

A preliminary report of these results has already appeared ('Truswell \& Kay, 1975).

\section{EXPERIMENTAL}

\section{Subjects}

The six subjects were postgraduate students of Queen Elizabeth College, three men and three women, aged 22-27 years. Most were research students in nutrition, and all were interested in the experiment and fully understood the regularity and reliability it required. 
Table I. Sample menu provided for volunteers on low-fibre and high-fibre experimental diets

Breakfast (g)
150 Orange juice
25 Kelloggs Cornflakes
25 Bread
5 Butter
30 Sugar (for whole day)
300 Milk (for whole day)

Lunch (g)
roo Bread
20 Butter
55 Salmon
17 Mayonnaise
17 Cucumber
50 Tomato
150 Yogurt
50 Muffin*

Dinner (g)

130 Turkey breast

4 Peanut oil

ro Butter

Io Maize starch

I 70 Potato

60 Peas

6o Banana Loaf*
Evening (g)

5० Muffin*

50 Bread

Io Butter

$3 \circ$ Cheese

20 Pickles

280 Beer

* Items in which white flour was isoenergetically replaced by II $5 \mathrm{~g}$ wheat bran in the high-fibre period.

\section{Diets}

Three subjects participated together in two separate 7 -week experiments, consisting of a 2 -week control period followed by a 3 -week high-fibre period and a second 2 -week control period. The diets were varied daily over a short, repeating cycle; this was a $3 \mathrm{~d}$ cycle in the first experiment and a $7 \mathrm{~d}$ cycle in the subsequent experiment. A sample menu is given in Table $\mathrm{I}$. The diets were based on food items which enabled rigid control of fat and cholesterol intake. Alcohol was included in stipulated quantities similar to usual intakes. All food was prepared and eaten in the metabolic unit with the exception of breakfast and a late evening snack which were pre-weighed and packed for home consumption. One subject lived in the metabolic unit full-time. The control diet was adequate in all nutrients but relatively low in cholesterol and crude fibre content. The fibre content of diets was estimated from crude fibre values in food tables (see footnote to Table 2).

Prewett's wheat bran (Prewett's Stone Flour Mills, Horsham, Sussex RHr2 IST) was substituted isoenergetically for white flour, using the Atwater coefficient of digestibility to calculate the energy value of bran (Watt \& Merrill, I963). The substitution was made in various muffins and quickbreads which were distributed throughout the day. Each serving contained $\mathrm{I}^{\mathrm{I}} \mathrm{5} \mathrm{g}$ bran and the number of servings of bran-substituted muffins was varied according to individual tolerance. Individual subjects took between 23 and $35 \mathrm{~g}$ bran/d, except for one who could not tolerate the bran (see later).

In addition, white bread (Sunblest Prairie Gold, sliced) in the control diet was isoenergetically replaced by $100 \%$ wholemeal bread (Mother's Pride sliced 100\% wholemeal). Intakes of bread ranged from 100 to $200 \mathrm{~g} / \mathrm{d}$ in different subjects. Changes in fat and protein intake due to these substitutions were negligible.

\section{Blood and faecal samples}

Venous blood was taken before breakfast on the last $3 \mathrm{~d}$ of each dietary period. Each subject remained in a reclining position for $20-30 \mathrm{~min}$ beforehand and minimum venostasis was used.

Five subjects collected faeces corresponding to the last $6 \mathrm{~d}$ of each dietary period. 
Table 2. Composition $(\mid d)$ of control and high-fibre diets given to normal volunteers*

(Mean values with ranges in parentheses)

$\begin{array}{lcc} & \begin{array}{c}\text { Control } \\ \text { diet }\end{array} & \begin{array}{c}\text { High-fibre } \\ \text { diet }\end{array} \\ \text { Energy (MJ) } & \begin{array}{c}10 \cdot 14 \\ (8 \cdot 07-12 \cdot 08)\end{array} & \begin{array}{c}10 \cdot 14 \\ (8 \cdot 07-12 \cdot 08)\end{array} \\ \text { Protein (g) } & 90 & 91 \\ & (78-100) & (79-101) \\ \text { Fat (g) } & 91 & 92 \\ & (74-108) & (75-109) \\ \text { Carbohydrate (g) } & 282 & 279 \\ & (208-337) & (205-334) \\ \text { Alcohoi (g) } & 18 & 18 \\ & (4-38) & (4-38) \\ \text { Crude fibre (g) } & 3.7 & 8.6 \\ & (2.7-4.8) & (6.8-10.6) \\ \text { Cholesterol (g) } & 0.52 & 0.52 \\ & (0.43-0.72) & (0.43-0.72)\end{array}$

* Calculated from food tables (McCance \& Widdowson, r960; Watt \& Merrill, 1963; Feeley, Criner \& Watt, 1972).

Transit time was measured by carmine markers (taken after the evening meal) at the beginning and the end of the $6 \mathrm{~d}$. The samples were individually collected in plastic bags and frozen. The samples for each period were mixed, weighed and two $5^{\circ} \mathrm{g}$ portions were freeze-dried and ground to a fine powder.

\section{Analyses}

Plasma cholesterol was measured by the method of Abell, Levy, Brodie \& Kendall (1952). An enzymic method was used for plasma triglyceride determination (Eggstein, 1966) and serum calcium was measured on a Vickers analyser (Vickers Medical Engineering, Basingstoke, Hants). Faecal bile acids and neutral steroids were measured by gas-liquid chromatography using the method of Evrard \& Janssen (I968) as modified by Mitchell, Findlay, Prescott, Eastwood \& Horn (1973).

Significance levels were calculated by Student's $t$ test for paired data. Mean values for the two control periods were compared against values for the wheat-fibre period (except for the values in Table 5).

\section{RESULTS}

\section{General}

Mean daily intakes of major and relevant nutrients are shown in Table 2.

Changes in body-weight were minimal, ranging from 0 to $\pm 700 \mathrm{~g}$ in any dietary period. All subjects remained healthy throughout the experiment. Total body-weight change for the whole of the experiment averaged $-0.2 \mathrm{~kg}$ (range $-\mathrm{x} \cdot 0$ to $+0.6 \mathrm{~kg}$ ). 
Table 3. Fibre consumption by normal volunteers given a high-fibre diet and changes in faecal weight and intestinal transit time

\begin{tabular}{|c|c|c|c|c|c|c|}
\hline \multirow[b]{2}{*}{ Subject } & \multirow[b]{2}{*}{$\begin{array}{c}\text { Bread } \\
(\mathrm{g} / \mathrm{d})\end{array}$} & \multirow[b]{2}{*}{$\begin{array}{l}\text { Bran } \\
(\mathrm{g} / \mathrm{d})\end{array}$} & \multicolumn{4}{|c|}{ Changes in high-fibre period } \\
\hline & & & $\begin{array}{c}\text { Added } \\
\text { crude } \\
\text { fibre } \\
(\mathrm{g} / \mathrm{d})\end{array}$ & $\begin{array}{c}\text { Change } \\
\text { in faecal } \\
\text { wet wt } \\
(\mathrm{g} / \mathrm{d})\end{array}$ & $\begin{array}{c}\text { Change } \\
\text { in mean } \\
\text { transit } \\
\text { time }(\mathrm{h})\end{array}$ & $\begin{array}{l}\text { Change in } \\
\text { mean no. } \\
\text { of bowel } \\
\text { movements/d }\end{array}$ \\
\hline $\mathrm{B}$ & 200 & $23 \cdot 0$ & 5.5 & +124 & -9 & +0.35 \\
\hline C & 150 & 0 & $2 \cdot 6$ & +64 & -18 & +0.65 \\
\hline I & 175 & 34.5 & $6 \cdot I$ & +55 & -20 & +0.35 \\
\hline $\mathrm{K}$ & 175 & 23.0 & $5 \cdot 1$ & +130 & -3 & +0.70 \\
\hline$S$ & 100 & 23.0 & $3 \cdot 8$ & $+9 \mathrm{x}$ & -33 & +1.70 \\
\hline $\mathrm{T}$ & 200 & $34 \cdot 5$ & $6 \cdot 5$ & +100 & -7 & +0.60 \\
\hline Mean & 167 & 23.0 & $4 \cdot 9$ & +94 & -15 & +0.73 \\
\hline
\end{tabular}

\section{Fibre intake}

Intakes of fibre in individual subjects are given in Table 3.

One subject (C) developed abdominal cramps and nausea on the addition of bran to the diet. Bran was discontinued in this subject and wheat fibre continued only in the form of wholemeal bread ( $15 \circ \mathrm{g} / \mathrm{d}$ ) (Table 3 ).

\section{Faecal weights and transit time}

The mean daily faecal weight in the last weeks of the two control periods was $125 \mathrm{~g}$ (range 59-194 g). During the bran period, this increased significantly to $225 \mathrm{~g}$ (range I 54-290 g) $(P<0.0 \mathrm{I})$. The changes in individual subjects are shown in Table 3. This was largely due to an increase in the water content of the faeces (mean $82 \mathrm{~g}$ control, $154 \mathrm{~g}$ on bran) while the dry weight of the faeces increased from an average of $32 \mathrm{~g}$ control to $53 \mathrm{~g}$ on bran. The percentage of water in faeces was $71 \%$ in control periods and $74 \%$ on bran.

Mean gastrointestinal transit time decreased during the high-fibre period but this change was not significant and was most notable in those subjects with an initially long transit time.

Bowel movements increased from a mean of 0.95 (range $0.6-1.4$ )/d in the control periods to a mean of $\mathrm{I} \cdot 7$ (range $1 \cdot 0-2 \cdot 7) / \mathrm{d}$ during the high-fibre period. This was statistically significant $(P<0.02)$.

\section{Plasma lipids}

Plasma cholesterol and triglyceride concentrations were not altered by the addition of wheat fibre to a low-fibre diet for a 3 -week period (Table 4, Fig. I).

Serum Ca levels were not lowered (Table 4 ) by the inclusion of wheat fibre. All diets contained over $700 \mathrm{mg} \mathrm{Ca} / \mathrm{d}$.

\section{Faecal steroids}

The addition of wheat fibre to the diet resulted in a decreased concentration of faecal bile acid and neutral steroids due to the bulking effect of fibre. The total daily 
Table 4. Plasma concentrations of cholesterol and triglycerides and serum concentrations of calcium in normal volunteers given control and high-fibre diets

(Mean values with ranges in parenthesis for six determinations)

\begin{tabular}{|c|c|c|c|}
\hline & $\begin{array}{l}\text { Control } \\
\text { period I }\end{array}$ & $\begin{array}{c}\text { High-fibre } \\
\text { diet }\end{array}$ & $\begin{array}{l}\text { Control } \\
\text { period } 2\end{array}$ \\
\hline Cholesterol (mmol/l) & $\begin{array}{c}5 \cdot 26 \\
(4 \cdot 17-7 \cdot 23)\end{array}$ & $\begin{array}{c}5.57 \\
(4 \cdot 35-7 \cdot 02)\end{array}$ & $\begin{array}{c}5 \cdot 41 \\
\left(4 \cdot 35^{-7} \cdot 36\right)\end{array}$ \\
\hline Triglycerides ( $\mathrm{mmol} / \mathrm{l})$ & $\begin{array}{c}0.95 \\
\left(0.68-I . I_{3}\right)\end{array}$ & $\begin{array}{c}0.90 \\
(0.72-1.07)\end{array}$ & $\begin{array}{c}0.93 \\
(0.80-I \cdot 05)\end{array}$ \\
\hline Serum $\mathrm{Ca}(\mathrm{mmol} / \mathrm{l})$ & $\begin{array}{c}2 \cdot 43 \\
\left(2 \cdot 3^{8}-2 \cdot 48\right)\end{array}$ & $\begin{array}{c}2 \cdot 45 \\
\left(2 \cdot 35^{-2 \cdot 5}\right)\end{array}$ & $\begin{array}{c}2 \cdot 50 \\
(2 \cdot 42-2 \cdot 53)\end{array}$ \\
\hline
\end{tabular}

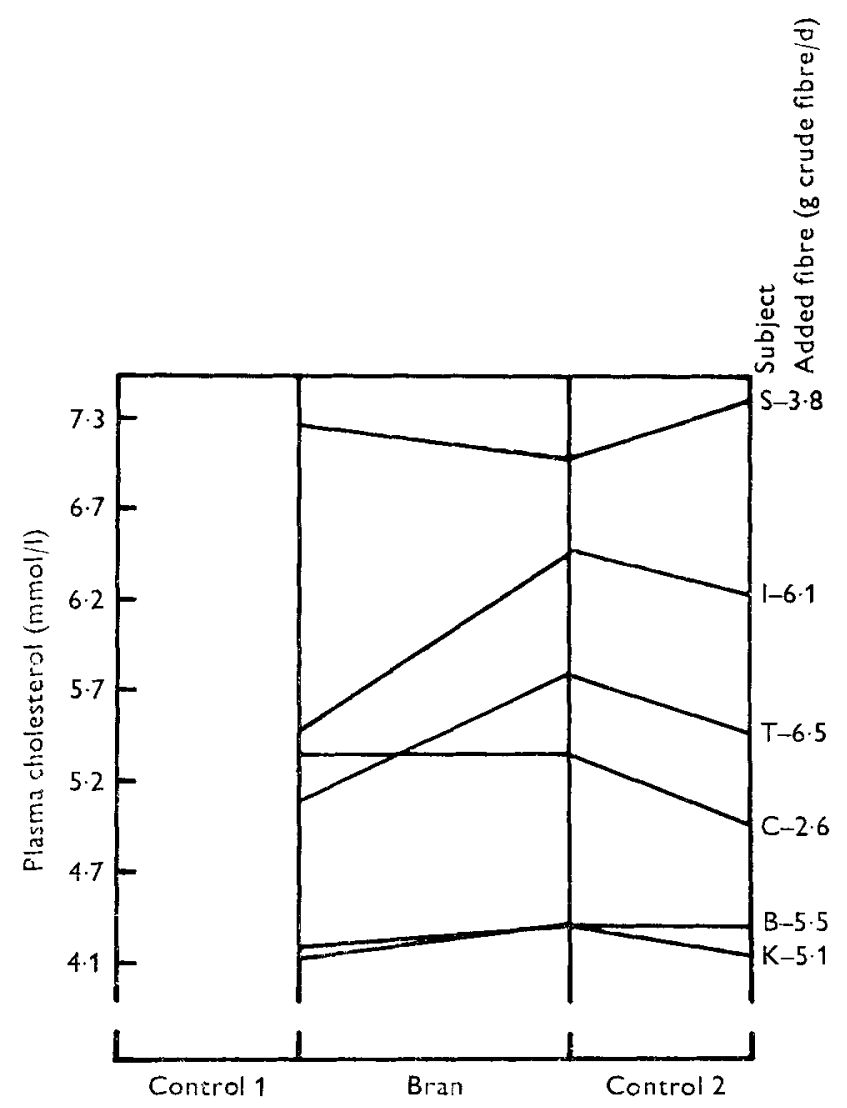

Fig. I. Changes in plasma cholesterol concentrations in individual subjects on changing from the control to the high fibre (bran) diet and back again to the control diet. Each inflexion of an individual's line is the mean of three determinations on consecutive days. 
Table 5. Faecal steroid excretion ( $m g / d)$ by normal volunteers given control and high-fibre diets during the last $6 d$ of each dietary period

(Mean values with ranges in parenthesis for five determinations)

\begin{tabular}{|c|c|c|c|}
\hline & $\begin{array}{l}\text { Control } \\
\text { period I }\end{array}$ & $\begin{array}{c}\text { High-fibre } \\
\text { diet }\end{array}$ & $\begin{array}{l}\text { Control } \\
\text { period } 2\end{array}$ \\
\hline Lithocholic acid & $\begin{array}{c}77 \\
(46-120)\end{array}$ & $\begin{array}{c}72 \\
(55-83)\end{array}$ & $\begin{array}{c}\text { I I I } \\
(53-174)\end{array}$ \\
\hline Deoxycholic acid & $\begin{array}{c}\text { I65 } \\
(50-226)\end{array}$ & $\begin{array}{c}150 \\
(112-204)\end{array}$ & $\begin{array}{c}25^{\circ} \\
(11-353)\end{array}$ \\
\hline Total bile acids & $\begin{array}{c}251^{\mathrm{a}} \\
(103-353)\end{array}$ & $\begin{array}{c}233^{\mathrm{b}} \\
(186-294)\end{array}$ & $\begin{array}{c}374^{\mathrm{ab}} \\
\left(234^{-545}\right)\end{array}$ \\
\hline Coprostanol & $\begin{array}{c}\text { I } 4 \text { I } \\
(\mathrm{I} I-244)\end{array}$ & $\begin{array}{c}126 \\
(12-218)\end{array}$ & $\begin{array}{c}183 \\
(221-268)\end{array}$ \\
\hline Cholesterol & $\begin{array}{c}I 24 \\
(28-321)\end{array}$ & $\begin{array}{c}130 \\
\left(25^{-277}\right)\end{array}$ & $\begin{array}{c}128 \\
(17-319)\end{array}$ \\
\hline Neutral steroids & $\begin{array}{c}265^{\mathrm{c}} \\
(175-335)\end{array}$ & $\begin{array}{c}256^{d} \\
(173-335)\end{array}$ & $\begin{array}{c}3 \text { I I }^{\mathrm{cd}} \\
(235-406)\end{array}$ \\
\hline
\end{tabular}

$\mathrm{a}, \mathrm{b}, \mathrm{c}, \mathrm{d}$, indicate significant differences $(P<0.05$ or better $)$ in paired $t$ tests.

faecal steroid excretion did not change during the high-fibre period but increased in the second control period (Table 5). Although the means of the values for the ist and and control periods were not significantly different from those on wheat fibre, both neutral steroid and total bile acid excretions were significantly larger in the second control period than in the high-fibre period.

There was no change in the relative proportions of faecal bile acids.

\section{DISCUSSION}

Although a reduction in serum $\mathrm{Ca}$ concentration in subjects taking wheat bran has been recorded (Heaton \& Pomare, 1974), such an effect was not confirmed by subsequent experiments (Connell, Smith \& Somsel, 1975; Heaton, Manning \& Hartog, 1976) or in the present study. The phytic acid of bran could interfere with $\mathrm{Ca}$ absorption and, in the present study $\mathrm{Ca}$ intake was lower when wholemeal bread replaced white. The former contains only $26 \mathrm{mg} / \mathrm{lo0}$ g compared with $90 \mathrm{mg} / \mathrm{lo0} \mathrm{g}$ in the latter (McCance \& Widdowson, 1960).

However, over a relatively short period of time bran and wholemeal bread did not lower the serum $\mathrm{Ca}$ concentration. Long-term studies would be required to determine whether continuous consumption of large amounts of bran would lead to a negative Ca balance.

Serum triglycerides were lower in one study, reported by Heaton \& Pomare (1974) at a mean intake of $38 \mathrm{~g}$ bran/d. Some of their patients had initially high triglyceride concentrations and might also have had disturbances of bile acid metabolism, as indicated by the presence of gall-stones or previous cholecystectomy. A later trial by Heaton's group (Durrington, Wicks \& Heaton, I975) demonstrated that $3^{\circ} \mathrm{g}$ bran/d had no effect on the serum triglycerides of subjects with initially low concentrations 
similar to those in the present communication. Heaton \& Pomare (1975) suggested that only patients with hypertriglyceridaemia may respond to bran. But Bremner, Brooks, Third \& Lawrie (1975) in a recent paper reported that $5 \circ \mathrm{g}$ bran/d did not lower serum lipids in five patients with type IV hyperlipidaemia. Other studies have confirmed the lack of effect of wheat fibre on serum triglycerides (Connell et al. 1975; Jenkins, Hill \& Cummings, 1975; Persson, Ruby, Fønns-Bech \& Jensen, 1975; Heaton et al. 1976).

As to plasma cholesterol, Jenkins et al. (1975) found no reduction in six male volunteers consuming $36 \mathrm{~g}$ wheat fibre/d for a 3-week period. Similarly, Connell et al. (1975) reported that the addition of $2.5-4.5 \mathrm{~g}$ crude fibre/d in the form of a bran cereal did not alter cholesterol concentration in twenty-two healthy students participating in an I I-week trial. It was further demonstrated by Eastwood et al. (I973) that I $6 \mathrm{~g}$ bran/d fed to eight normal subjects for a 3-week period did not lower serum cholesterol and Heaton et al. (1976) administered wheat fibre in the form of wholemeal bread for 19 weeks without finding any reduction in blood lipids. Only Persson et al. (1975) have reported that plasma cholesterol was reduced after 6 weeks of bran consumption. However, the mean change was only $-7 \%$. Control values after bran consumption ceased were not reported and the patients' average age was 76 years.

The wheat fibre in our subjects came from wholemeal bread in all six subjects and also from bran in five of the six. Most commercially available crude brans are similar in composition except for one that we did not use (Allinson's, which is finely ground and contains substantial amounts of germ and endosperm as well).

The study described here has shown, in agreement with the majority of other reports, that the addition of wheat fibre equivalent to $153^{-382} \mathrm{~g}$ of whole-wheat bread or 28-7 $\mathrm{g}$ bran/d, to a controlled diet for a 3-week period does not lower plasma lipid levels in healthy young adults. The amount of fibre added was sufficient to affect stool bulk and intestinal motility.

It has been suggested that certain classes of dietary fibre may alter faecal steroid excretion. However, Pomare, Heaton, Low-Beer \& White (1974) found no change in the half-life of labelled cholic and deoxycholic acids administered to subjects consuming $57 \mathrm{~g}$ bran $/ \mathrm{d}$. This indicates that bran has little if any bile-acid binding capacity in vivo. Walters, McLean-Baird, Davies, Hill, Drasar, Southgate, Green \& Morgan (1975) reported that neither faecal bile acid nor neutral steroid excretion increased in subjects receiving $39 \mathrm{~g}$ bran/d. A slight but significant increase in bile acid excretion in normal volunteers taking $20 \mathrm{~g}$ bran/d was found by Eastwood's group (Findlay, Smith, Mitchell, Anderson \& Eastwood, 1974). In the same study, patients with diverticular disease tended to have lower bile acid excretion when they were given bran.

In a separate experiment Eastwood, Kirkpatrick, Mitchell, Bone \& Hamilton (1973) reported a rebound phenomenon in bile acid excretion after stopping bran. Mean faecal bile acid excretion was virtually the same in the last week of the first control and the last week of a 3 -week bran period but increased in the succeeding control period. In our study, faecal steroid excretion showed a similar pattern and these results suggest that some alteration in the enterohepatic circulation may have occurred 
as a consequence of bran consumption, but the mechanism for such an effect is unclear. It has been demonstrated by Pomare \& Heaton (1973) that bile acid patterns may be modified in the upper intestine by feeding bran. They report an increase in the ratio, chenodeoxycholate: deoxycholate in duodenal aspirates, implying that bran reduced the degradation of bile salts by colonic bacteria. The results reported here, however, do not indicate any difference in the proportions of faecal bile acids before or after bran.

A possible important effect of bran, observed in the present and other studies, is a significant increase in faecal bulk resulting in a dilution of faecal bile acids. Hill (1974) suggests that if certain bile acids, such as deoxycholic acid, are potential carcinogens or co-carcinogens, their concentration in the faeces is of more importance than the total daily excretion.

The effect of wheat fibre on stool bulk and laxation is direct and unequivocal. This form of dietary fibre, however, does not appear to reduce plasma lipids, at least in trials of a few weeks. This is not to say that other types of dietary fibre may not affect plasma lipid concentrations. We and other workers have been investigating pectin, for example, from this point of view (Truswell \& Kay, 1975; Jenkins et al. 1975).

We would like to thank the members of the Departments of Nutrition and Physiology at Queen Elizabeth College who participated in these experiments. Drs Ebringer and Al-Samarrae kindly helped with taking some blood samples and Dr D. Bender of the Middlesex Hospital arranged for the serum $\mathrm{Ca}$ determinations. Financial support was provided by the British Heart Foundation. Bran was donated by Prewetts Ltd, Horsham, Sussex.

\section{REFERENCES}

Abell, L. L., Levy, B. B., Brodie, B. B. \& Kendall, F. E. (1952). F. biol. Chem. r95, 357.

Bremner, W. F., Brooks, P. M., Third, J. L. \& Lawrie, T. D. V. (1975). Br. med. F. iii, 574.

Connell, A. M., Smith, C. L. \& Somsel, M. (1975). Lancet i, 496.

Durrington, P., Wicks, A. C. B. \& Heaton, K. W. (1975). Lancet ii, 133.

Eastwood, M. (1969). Lancet ii, 1222.

Eastwood, M. A. \& Hamilton, D. (1968). Biochim. biophys, Acta 152, 165.

Eastwood, M. A., Kirkpatrick, J. R., Mitchell, W. D., Bone, A. \& Hamilton, T. (1973). Br. med. F. iv, 392 .

Eggstein, N. (1966). Klin. Wschr. 44, 267.

Evrard, E. \& Janssen, G. (r968). F. Lipid Res. 9, 226.

Feeley, R. M., Criner, P. E. \& Watt, B. K. (1972). F. Am. diet. Ass. 6r, 134.

Findlay, J. M., Smith, A. N., Mitchell, W. D., Anderson, A. J. B., \& Eastwood, M. A. (1974). Lancet i, 146.

Heaton, K. W., Manning, A. P. \& Hartog, M. (1976). Br. F. Nutr. 35, 55.

Heaton, K. W. \& Pomare, E. W. (1974). Lancet i, 49.

Heaton, K. W. \& Pomare, E. W. (1975). Lancet i, 800 .

Hill, M. J. (1974). Digestion Ir, 289.

Jenkins, D. J. A., Hill, M. S. \& Cummings, J. H. (1975). Am. F. clin. Nutr. 28, 1408.

Kay, R. M. \& Truswell, A. S. (1975). Proc. Nutr. Soc. 34, I7 A.

McCance, R. A. \& Widdowson, E. M. (r96o). The Composition of Food. London: HM Stationery Office. McConnell, A. A. \& Eastwood, M. A. (1974). F. Sci. Fd. Agric. 25, 145 I.

Mitchell, W. D., Findlay, J. M., Prescott, R. J., Eastwood, M. A. \& Horn, D. B. (1973). Gut 14, 348. Persson, I., Ruby, Kn., Fønns-Bech, P. \& Jensen, E. (I975). Lancet ii, 1208.

Pomare, E. W. \& Heaton, K. W. (1973). Br. med. Y. iv, 262.

Pomare, E. W., Heaton, K. W., Low-Beer, T. S. \& White, C. (1974). Gut I5, 824, Abstr. p. ro. 
Robertson, J. (1972). Nature, Lond. 238, 290.

Trowell, H. (1972a). Am. F. clin. Nutr. 25, 926.

Trowell, H. (1972b). Eur. F. clin. biol. Res. I7, 345.

Trowell, H. (I975). In Refined Carbohydrate Food and Disease. Some Implications of Dietary Fibre, p. 195 [D. P. Burkitt and H. C. Trowell, editors]. London and New York: Academic Press.

Trowell, H., Painter, N. \& Burkitt, D. (1974). Am. F. dig. Dis. 19, 864.

Truswell, A. S. \& Kay, R. M. (1975). Lancet i, 922.

Walters, R. L., McLean-Baird, I., Davies, P. S., Hill, M. J., Drasar, B. D., Southgate, D. A. T., Green, J. \& Morgan, B. (1975). Br. med. \%. 2, 536 .

Watt, B. K. \& Merrill, A. L. (1963). Composition of Foods. Washington, D.C.: US Department of Agriculture. 